\title{
Tajemnica oczywista albo cnota uważności, czyli o tym, jak helleńsko-romańskim tropem poetyki dotrzeć do intymnego źródła poezji
}

Streszczenie: W poezji Konstantego Ildefonsa Gałczyńskiego dominuje tonacja buffo. Poeta bez wątpienia intencjonalnie używa tonu lekkiego, języka kpiny i żartu, intelektualnej ironii i surrealistycznego obrazowania. Nader często odwołuje się przy tym do tradycji poezji łacińskiej i romańskiej późnego średniowiecza oraz wczesnego renesansu. Idąc tym tropem, autor artykułu odsłania w poetyce Gałczyńskiego cechę "liryczności”, uznając ją za esencjalną kategorię specyficznie „poetyckiej" relacji człowieka ze światem. W historycznych dygresjach badacz tropi obecność tego pierwiastka w oralnej poezji greckiej, łacińskiej i prowansalskiej, aż po piśmienne formy liryki renesansowej. Znaczna część artykułu poświęcona jest interpretacji wiersza Wizyta, który autor uznaje za przykład doskonałej realizacji zasady liryczności w poezji, a zarazem wykazuje, w jaki sposób wiersz ów czyni poezję jako taką swoim tematem. Konkluzją komparatystycznego i strukturalno-performatywnego studium tekstu, przeprowadzonego od najdrobniejszych elementów formy wierszowej aż po odsłonięcie fundamentalnej zasady

\footnotetext{
Artur Grabowski - dr hab., profesor na Wydziale Polonistyki Uniwersytetu Jagiellońskiego w Krakowie, zajmuje się głównie poezją i dramatem XX wieku, komparatystyką, teorią literatury i teatru. Jest autorem tomów wierszy, dramatów, prozy i esejów o literaturze, sztuce i filozofii.
} 
jego istnienia, okaże się filozoficzna refleksja na temat „poetyckości” jako kategorii poznawczej i egzystencjalnej jednocześnie.

Słowa-klucze: Gałczyński, poezja polska, poezja europejska, komparatystyka, poetyka, filozofia poezji.

\section{Mystery of "the obvious" or the virtue of mindfulness. How to reach the intimate source of poetry by the Greek and Roman trail}

Summary: Konstanty Ildefons Gałczyński's poetry seems to be dominated by the buffo tone. The poet intentionally, the language of ridicule and joke, intellectual irony and surrealistic imagery. Additionally, he often refers to the tradition of Latin and Romanesque poetry of the late Middle Ages and the early Renaissance. Following this lead, the author of the article reveals the characteristic of "lyricism" in Gałczyński's poetics, recognizing it as the essential category of a specifically "poetic” relationship between man and the social and natural environment. In historical digressions, the researcher traces the presence of that element in oral Greek, Latin and Provencal poetry, up to written forms of Renaissance verse. Much of the article is devoted to the interpretation of the poem „Wizyta”, which the author regards as an example of perfect implementation of the principle of lyricism in poetry, and at the same time shows how makes poetry its own subject. The conclusion of this comparative and structural-performative study of the text, carried out from the smallest elements of the verse form to the unveiling of the fundamental principle of its existence, will be a philosophical reflection on "poetics” as a cognitive and existential category.

Key words: Gałczyński, Polish poetry, European poetry, comparative poetics, philosophy of poetry. 


\section{1}

Na pierwszy rzut oka wiersze Gałczyńskiego sprawiają wrażenie „lekkich", czyli łatwych w zrozumieniu i przyjemnych w lekturze, zawierających proste i raczej beztroskie przesłanie. Że tak być nie musi starało się udowodnić wielu komentatorów. Odmienność ich odczytań szła jednak najczęściej w jednym kierunku - wzbogacano interpretację poematów o aluzje i odniesienia do wydarzeń historycznych, osób lub ideologicznych sporów, żeby niejako obronić poetę przed zarzutem eskapizmu, estetyzmu, nihilistycznego dandyzmu lub wręcz cynicznego egoizmu. Wskutek tego poetyka wierszy - ich ostentacyjnie piosenkowy rytm, ich nasycenie dowcipem i kpiną, ich bezpretensjonalna apoteoza zwyczajności, ich szkicowa dezynwoltura miała zostać wzięta w cudzysłów i takim sposobem sprowadzona na poziom powierzchownego sztafażu, kryjącego głębsze jakoby treści. A przecież owa trywialność, w połączeniu ze społeczną postawą chuligana, rozmaitymi wcieleniami archetypowego trickstera, pojawia się w twórczości Gałczyńskiego tak często, że sprawia wrażenie ostentacyjnie manifestowanej, świadomie czy instynktownie, jednak nader konsekwentnie kontynuowanej - strategii poezjowania.

Twórca wyraźnie odwołuje się do tradycji, wskazuje nawet konsekwentnie jeden trop - jest nim łacińskie średniowiecze; ale nie to oficjalnie kościelne, lecz to heretycko ludowe, wiążące profesję artysty raczej z rzemiosłem niż z mistyką. Cofając się tym szlakiem od ,jesieni średniowiecza” napotykamy Dantego, słodki styl Toskańczyków, wczesne arcydzieła wernakularnej literatury europejskiej, przemierzamy kulturę trubadurów, odnajdując jej romańskie korzenie w miłosnej liryce rzymskiej, a wreszcie docieramy do greckich źródeł samej liryczności. Gałczyński odsyła czytelnika do tej tradycji nie tylko przywołując często jej atrybuty, ale przede wszystkim za sprawą świadomie przyjętej estetyki, czyli sposobu konstruowania wiersza na poziomie wersyfikacji i stylistyki. Jednocześnie jednak przejmuje charakterystyczną dla tej formacji myślowej filozofię poezji i poety - i to ona jawi się ostatecznie zasadniczym rysem oryginalności autora... Wizyty. Bo ten właśnie krótki wiersz zamierzam uczynić egzemplarycznym przedmiotem moich rozważań.

Proszę, proszę, rozgość się, serdeczny, rozejrz się dokładnie po wszystkim; 
to jest czajnik - prawda jaki śmieszny?

z gwizdkiem.

To mruczenie? Powiem ci w sekrecie:

jest mruczeniem kota Salomona.

A ta pani zamyślona, z kwiatami -

to moja żona.

Wiersz daje się zrealizować w dwóch co najmniej gatunkach mowy: jako zaproszenie i powitanie w formie autoprezentacji, lub jako canzonieta, piosneczka rymowana, rytmiczna, złożona z dwóch symetrycznych, acz nie jednakowych strofek niby-safickich. Obie formuły odsyłają do antycznego wzorca poezji okolicznościowej, czy też raczej akcydentalnej, znanej z klasycznej, bo greckiej jeszcze, potem rzymskiej i renesansowej tradycji. Pozorna sprzeczność między tymi dwiema formami dałaby się chyba uzgodnić w formule fraszki, gatunku wywiedzionego ze starożytnej poezji biesiadnej.

Zasadniczą cechą fraszki jest jej, programowa wręcz, bezużyteczność. Podkreśla to nawet kolokwialne użycie tego słowa, które mamy za synonim czegoś niewartego uwagi, ze względu na tego czegoś małą wartość, ale też, infantylną ponoć, bezproblematyczność. Fraszka to coś spoza życia, któremu powagę zapewniają jakoby jedynie sprawy przyczyniające się do jego podtrzymania, rzeczy, działania lub idee do życia konieczne. Fraszką byłoby więc to, co zasadniczo niepotrzebne, jakiś zbytek wobec niezbywalnego. Fraszka nie wymaga przeto wysiłku ani zaangażowania, przeciwnie, zjawia się sama i niech nie waży się absorbować uwagi. To twór nie $\mathrm{z}$ tego świata, bo spoza świata woli i konieczności, samoistny i samozwrotny.

Wizyta faktycznie brzmi jak fraszka, wręcz prowokacyjnie zdaje się podsuwać czytelnikowi frywolną interpretację. Jednak fraszkowy trop tradycji wiedzie też w stronę zupełnie innych emocji. Fraszka ma bowiem w tradycji polskiej poezji pozycję szczególną - ze względu na fakt, iż wprowadza ją do literackiego obiegu sam Jan Kochanowski, który od razu też nadaje jej funkcje zadziwiająco różnorodne, obejmując nimi obszar bogatszej, niżby sugerowała nomenklatura, tematyki. Najprościej mówiąc, ojciec polskiego wiersza wzbogaca fraszkę o wymiar osobisty, filozoficzny nawet, czyniąc z niej modelowy utwór... liryczny, bardziej nawet odpowiadający „lirycznym” emocjom niż 
pieśń, w poetyce osobistej czarnoleskiego mistrza przeznaczona do wyrażania uczuć podniosłych lub stanów bukolicznych. W ten sposób nasz renesansowy lirnik na wieki wiąże ze sobą swobodę i performatywność wiersza z intymną tematyką jego treści, a z dowcipnego tonu czyni wehikuł pozwalający wyrazić głęboką mądrość doświadczenia - życia w jego esencjalnej trywialności.

Dla Gałczyńskiego, „rzeczy czarnoleskiej” dziedzica, czymś takim jest poezja i wszystko, co za sprawą twórczej erupcji zjawia się na tym świecie z jakiegoś innego świata. Ostentacyjna frywolność i szkicowość wielu jego wierszy - których treścią są często: zabawy, gry, wygłupy, przedstawienia - zdaje się manifestować, że ich zasadniczym tematem jest sama ta aktywność - ludzka potrzeba i ludzka zdolność tworzenia... rzeczy niepotrzebnych do życia. Niepotrzebnych przynajmniej na razie, póki powaga życia polega (a jakże trudno nam pomyśleć inaczej) na samym podtrzymywaniu egzystencji. Wiersz taki wyraża fundamentalną doczesność, ziemskiego „przebytu” konieczność i tymczasowość zarazem. Pośrednio zatem dowodzi istnienia i szczególnej ważności sfery nieznanej, niedoświadczanej na co dzień, bo w teraźniejszości obecnej „negatywnie" jako przepowiedziana człowiekowi wieczność jego duchowej istoty. Tą swoją radosną lub refleksyjną tonacją poezja, paradoksalnie, zdaje się zbliżać do... teologii, bo kompromituje pragmatystów tak samo jak ideologów. Poezja, pójdźmy za Gałczyńskim, i sztuka w ogóle, musi być dziedziną szarlatanów.

Mamy więc przed sobą rymowaną anegdotkę, karykaturalną scenkę z kłaniającym się jakby z kabaretowej sceny solistą, notatkę rzuconą mimochodem i bezceremonialnie nieukończoną, bo przecież dałoby się taki wiersz rozbudować z każdego miejsca. Jak większość rymowanek Sztukmistrza, i ta wydaje się zrazu „o niczym”, a zaraz potem o tym jednym znowu - o poezji samej - czyli o tym, co (jakim cudem?) rodzi się spontanicznie, pochodzi znikąd i zostaje po nic. Autoironia, a nawet humor, które wspomagać mają skuteczność gestu retorycznego, podszyte są tu rytmiczną i rymową strukturą, sugerującą frywolność. A przecież sensem zawartego w wierszu przesłania jawi się wezwanie do uważności, zaś wyłaniający się z tych strofek obrazek zastyga w konterfekt „portretu we wnętrzu”, czyli w postać dzieła, jeśli nawet nie bardzo poważnego, to przecież przeznaczonego do kontemplacji.

Kontemplacja sytuuje się na przeciwnym biegunie wobec spekulacji, choć obie mogą zmierzać w tym samym kierunku i dotyczyć tego samego przedmiotu. Kontemplacja wszakże wymaga niejako zawieszenia spekulacyjne- 
go wysiłku, inicjuje się w warunkach swoistej bezintencjonalności. Dlatego w wierszu lirycznym głębia przedmiotu refleksji nie wyraża się w myśli wpisanej w sylogizmy, lecz uobecnia się jako wniosek pochodzący ze studium formy, traktowanej... No właśnie: poważnie! Bo tylko wtedy działającej skutecznie, jeśli w procesie lektury branym będzie pod uwagę każdy jej, najdrobniejszy nawet, element. Takie czytanie „mimowolnie uważne”, czytanie dopuszczające działanie czynników pozarozumowych, właściwe jest tylko poezji - poezji lirycznej właśnie. Kiedy się w taki liryczny nastrój pozwolimy wciągnąć, to forma wiersza sama w sobie stanie w centrum uważnego czytania, w językowych figurach wierszowości wyrazi się wówczas sama istota poetyckości. Treścią bowiem - nazwijmy ją górnolotnie: filozoficzną - kaprysu Gałczyńskiego jest, ni mniej ni więcej, tylko wewnętrzny pejzaż twórczej wrażliwości poety; rzec by można: autoprezentacja jego uświadomionej najintymniejszej „poetyczności”.

\section{2}

Liryczność wiąże poezję z sytuacją wykonania - śpiewu solowego przy akompaniamencie instrumentu strunowego. Nie oznacza to jednak po prostu piosenki, lecz całą sytuację performatywną, której skutkiem oczekiwanym ma być konkretna kategoria estetyczna, coś, co nazywamy potocznie „nastrojem”. Sztuczne wywołanie „nastroju” - czyli powtórzenie wewnętrznego, aczkolwiek usytuowanego w wyjątkowych okolicznościach zewnętrznych, stanu emocjonalnego znanego z doświadczenia, a więc czegoś już uprzedmiotowionego w naszej emocjonalnej pamięci - to pierwotny cel sztuki, jej istotowo mimetyczny status.

Naśladowczość liryki, w przeciwieństwie do epiki, nie dotyczy bowiem zdarzeń i osób, lecz otaczającej je aury, mimetyczna możność powtórzenia wyłania się ze swoistej mieszanki emocji, wynikających z określonej sytuacji spotkania poety z człowiekiem lub miejscem w niejasny sposób wyróżnionymi z otoczenia. Przy czym - nie może to być coś niezwykłego, wówczas bowiem sytuacja się „dramatyzuje”, lecz właśnie coś pozornie nieznaczącego, codziennego. Lektura wiersza lirycznego nie ma przeto naśladować procedury myślenia jako wnioskowania, nie ma też przypominać procesu deszyfracji znaków. Intencją wiersza lirycznego jest raczej wywarcie na czytającym określonego wrażenia, które wprowadzi go w stan pozwalający doświadczyć tego, 
czego doświadczyć można wyłącznie za sprawą lektury wiersza: poetyckiego bycia w świecie.

Zachodnia estetyka, skłaniając się ku kategoryzowaniu form wedle porządków organizacji językowej tekstu, nie eliminuje wprawdzie całkowicie kategorii wrażenia jako wyróżnika genologicznego, jednak sytuuje go raczej w tle gatunkowych klasyfikacji. Wyrazem tego jest tradycyjny podział rodzajowy na: lirykę, epikę i dramat. Próby uzasadnienia podziału piśmiennictwa artystycznego li tylko organizacją materiału słownego zawsze budziły wątpliwości, żeby w końcu skompromitować się na dobre na progu nowoczesności, w dorobku romantyków. Stosują oni powyższe określenia już tylko, ale za to celowo, do zasugerowania emocjonalnych skutków lektury, a tym samym do stworzenia presupozycji hermeneutycznej; co zresztą odnosi się w tym czasie nie tylko do literatury. Odróżnia to nasz, helleńsko-łaciński, sposób obcowania z literaturą od tego, z czym mamy do czynienia w kulturach Wschodu, gdzie kategorie estetyczne właśnie, czyli określone „nastroje”, mają zastosowanie w porządkowaniu gatunkowym ${ }^{1}$. Nie chodzi o wywołanie wzruszeń dla nich samych, chodzi o stworzenie warunków rozumienia jako ustanowienia relacji między poetą a czytelnikiem, która pozwoli na możliwie pełne i trafne doświadczenie hermeneutyczne. Tego rodzaju ujęcie wstępne jawi się jako konieczne, aby autor i odbiorca mogli porozumieć się na gruncie trafnie zlokalizowanej konwencji, również wówczas, kiedy sama ta konwencja ulec by miała jakiemuś odkształceniu. Nastroje, jako kategorie estetyczne, są więc warunkiem trwałości i żywotności tradycji. Tym samym pozwalają one podtrzymać proces nieprzerwanej eksploracji tajemniczego źródła, z którego wypływa to, co rozbudza i zaspokaja pragnienia użytkowników poezji - tworu, poza tym, co sama sobą oferuje... bezużytecznego.

Jako utajona w tradycji formuła, liryczność opuściła terytorium realnej sytuacji performatywnej, przechodząc na terytorium nastroju. Dzięki temu utrwalić się mogła w postaci odmiennej niż praktyczna wykonawczość w samym tekście. Oryginalnie związana ze śpiewem, musiała z czasem wypracować właściwe sobie tylko sposoby uobecniania się w piśmie, a więc praktycz-

1 P. J. Chaudhury, Indian Poetics, „The Journal of Aesthetics and Art Criticism” 1965, Vol. 24, No. 1. Dostęp przez: https://www.jstor.org/stable/428209?seq=1\#page_scan_tab_contents [1.06.2019 r.]. 
nie w tych elementach kompozycji językowej, które pismo zdolne jest utrwalić i umożliwić ich odtworzenie. Odtworzenie, dodajmy, w postaci aktualizowalnej jako zakotwiczony w odmiennym medium analogon postaci źródłowej. Celem nie jest wywołanie wzruszeń dla nich samych, chodzi o stworzenie warunków rozumienia jako ustanowienia relacji między poetą a czytelnikiem, która pozwoli na możliwie pełne i trafne doświadczenie hermeneutyczne.

\section{3}

W XIII wieku we Włoszech, w wyniku nałożenia się oralnej tradycji poezji wernakularnej prowansalskich (i nie tylko) trubadurów na rzymską lirykę miłosną, znaną z zapisów średniowiecznych łacinników, powstaje canzona forma wiersza pierwotnie tworzona w postaci pisanej, ale też od początku z intencją imitowania kompozycji oralnej, której źródłem jest poezja prowansalska (canso). Utrwali ją Petrarka, a jej bezpośrednim dziedzicem będzie włoski sonet ${ }^{2}$. Taka zapisana imitacja wokalizacji nie notuje dosłownie partytury wokalnej (śpiewania), ani nawet recytatywnej (mówienia), lecz oznakowuje zawartą w strukturze tekstu sugestię wykonawczą w postaci zarazem: performatywnie wariantywnej oraz takiej, która nie upodrzędnia funkcji semantycznej słowa wobec funkcji materiału wokalizy, jak ma to miejsce w nutowym zapisie pieśni przeznaczonej do śpiewania, lecz wzajemnie funkcje te od siebie uzależnia.

Skutkiem takiej intencji komponowania tekstu nie ma być oczywiście instrukcja realnego wykonania wokalizy, ani nawet naśladowanie jakichkolwiek jej materialnych cech, lecz poczucie obecności podmiotu wypowiedzi w trakcie jej, co prawda nie realnego, ale mimo to praktycznego, realizowania jako procedury werbalnej, muzycznej i performatywnej jednocześnie. Celem organizacji tekstu pisanego jest tutaj stymulowanie aktu takiej lektury (również cichej, bo i ta w istocie stymuluje głos, na dodatek w postaci idealnej), która skłaniałaby czytającego, w sposób przez niego niezupełnie kontrolowany, do utożsamienia aktu czytania tekstu z aktem jego wykonywania i utożsamienia

2 O. Holmes, Authority and Materiality in the Italian Songbook: From the Medieval Lyric to the Early Modern Madrigal. Dostęp przez: https:/www.academia.edu/39177439/ Authority_and_Materiality_in_the_Italian_Songbook_From_the_Medieval_Lyric_to the_Early_Modern_Madrigal [1.06.2019 r.]. 
siebie samego jako odbiorcy z twórcą i performerem. Nie będzie to oczywiście utożsamienie ontyczne, lecz empatyczne, czyli możność wywołania analogicznego doświadczenia na gruncie własnej egzystencji, czy to na zasadzie powtórzenia, czy też partycypacji. Nie chodzi o to, żeby doświadczyć tego, czego doświadczył twórca jako osoba prywatna, lecz tego, co wydarzyło się pomiędzy: jego/jej doświadczeniem życiowym a uniwersalną procedurą - poetyckim działaniem. Osiągnięta $\mathrm{w}$ ten sposób aura liryczności spowodować ma, że czytelnik obcować będzie z „przedmiotem poezji” - z tym, co za sprawą poezji, i dzięki niej tylko, dostępne jest ludzkiemu doświadczeniu.

Mimowolne podążanie za formułami wersyfikacji, za porządkiem rymów czy instrumentacji głoskowych, wzmacniane efektami zaburzenia składni, a w końcu komplikowanie przekazu poprzez użycie figur retorycznych zaciemniających transparencję treści, powoduje, że czytający skierowuje energię hermeneutyczną $\mathrm{w}$ kierunku przeżywania doświadczenia obcowania $\mathrm{z}$ tekstem, odwracając uwagę od świata przedstawionego. Funkcję poznawanej w trakcie lektury „rzeczywistości” przejmuje świat wewnętrzny czytelnika, jego emocjonalne reakcje i znakowe skojarzenia. Korzystając z tekstu w funkcji stymulatora działań fizyczno-emocjonalnych, czytający wprowadza się w stan odwróconej ekspresji - poddając się stymulacji tekstu, czyli ulegając jego impresywnej mocy, może niejako wrócić do rzeczywistości przeżycia, powtórzyć doświadczenie kreacyjne poety lub partycypować w tym, co je wywołało. Czytający nie stanie się oczywiście piszącym, ale czytany przez niego tekst stanie się dla niego analogonem doświadczenia aktualizacji aktu twórczego, w jego kreacyjnej i performatywnej postaci jednocześnie.

W kategoriach czysto formalnych z kolei efekt „liryczności” to emocjonalno-hermeneutyczny skutek wyrafinowanej i subtelnej gry ról, wzajemnie sfunkcjonalizowanych, tworzących swoistą (ekskluzywną) sytuację komunikacyjną, dynamiczną, ale wyłącznie mentalnie, dramaturgię - czytania bezgłośnej pieśni. Celem wierszowego ukształtowania tekstu będzie spowodowanie swoistej reakcji czytającego. Ma on mianowicie mimowolnie wejść w emocjonalno-mentalny kontakt z nadawcą i niemal mechanicznie reagować: przyjąć rolę wsłuchującego się w utwór... czytelnika, czyli kogoś, kto jednocześnie odbiera i wykonuje swoje własne czytanie jako performans quasi-wokalny na swój własny użytek. Taka multi- i trans-medialna aktywność możliwa jest, rzecz jasna, wyłącznie na gruncie praktyki mentalnej; indywidualnej, 
co prawda, atoli niezupełnie subiektywnej, lecz w jakimś sensie przebiegającej w przestrzeni umysłu uniwersalnego, funkcjonującego wedle procedur wyznaczonych przez konwencje utrwalone w tradycji, a zapisane i aktualizujące się w poetyce tekstu. Dzięki utrwalonym (i utajnionym, dodajmy) mechanizmom hermeneutyczno-wykonawczym, możliwym staje się cud: czytanie pisma jako słuchanie wokalizy, a nawet uczestniczenie w jej wykonywaniu. W istocie bowiem „czytelnik wiersza” pochodzi od „słuchacza wersów” i w głębi swojej psychiki tegoż „słuchacza” w sobie aktywizuje, kiedy przystępuje do lektury wiersza; wersyfikacja zaś pozwala mu „wykonać” utwór dla własnych uszu. Taki czytelnik słucha mentalnym uchem lektora, $w$ istocie więc - słucha siebie jako poetę. $\mathrm{Z}$ tego stopienia się autora i odbiorcy $\mathrm{w}$ jednego nad-wykonawcę powstaje persona liryczna - której udziałem jest doświadczenie rzeczywistości poetyckiej.

Liryka grecka - zarówno: archaiczna, klasyczna i helleńska - zakłada, że poeta to przede wszystkim autor techne wiersza, który poetycko dopuszcza (i w tym jego mistrzostwo) do głosu pewną rzeczywistość i eksponuje jej wysłowienie. Impresja zyskuje wówczas przewagę nad ekspresją, a poeta staje się tym, który odsłania (aletheia) ukrytą w rzeczywistości formę jej trwania, dowodząc tym samym, że natura skrywa w sobie swoją prawdziwszą - poetycką - postać. Dzięki znajomości pewnych formuł oraz uniwersalnego języka (koine), poezję można uprawiać (poiesis), czyli działać językowo i mentalnie w określony sposób, którego to działania skutkiem będzie poemat. Poeta nie mówi więc „od siebie”, lecz jest sługą prawdy, za co wspólnota wynagradza go, przyznając mu prawo do wyjątkowości. Poeta rzymski niejako towarzyszy swojemu wierszowi, ujawnia w nim swoją obecność; obecność wszakże raczej jako autora formy wypowiedzi, czasem też sytuacji mówienia. Bo zasadniczo poeta ukrywa się za wierszem jako osoba prywatna, kreując w zamian postać bohatera lirycznego. Rzymianin pracuje już bowiem nie w środowisku poezji, lecz w ramach tradycji poetyckiej. Forma łacińskich wierszy powstaje z materiału języka żywego (chociaż wciąż tylko w odmianie elitarnej), ale jego wersowe ukształtowanie i reguły komponowania utworów podporządkowują się skodyfikowanym formom wykonawczym, które siłą rzeczy stają się zasadami tworzenia. Reguł tych uczą się jednako słuchacze i czytelnicy. Kiedy pojawiają się trubadurzy, ich sytuacja społeczna znowu upodabnia się do tej z czasów wspólnoty helleńskiej, ale teraz anonimowy bohater liryczny zamienia się 
w postać Poety - sługi poezji. Dante dodaje do tego „Ja” jako człowieka uniwersalnego, Petrarka uczyni z siebie jednostkowe exemplum powszechnika. Za szczytowy moment tej ewolucji wypada chyba uznać Vita Nuova wielkiego florentczyka, zaś za etap już manieryczny cykl Sonety do Laury Petrarki.

Zdarzeniem przełomowym w procesie kształtowana się „liryczności” była właśnie poezja trubadurów i truwerów, powstająca na styku oralności i piśmienności. Wiemy, że funkcjonowała oralnie, ale znamy ją z zapisów tworzonych ówcześnie. Charakterystyczne jest w nich rozdzielenie notacji muzycznej i słownej, co w istocie odzwierciedla dwie formy twórczości, które poeta-śpiewak powinien połączyć w wykonaniu, a najlepiej również twórczo. Autor komponuje oba teksty równocześnie i na bieżąco, taki wiersz powstaje więc niejako w przytomności słuchacza, ale jako pełny tekst rezyduje w jego pamięci ${ }^{3}$. Wiersz jest więc niejako własnością wspólną twórcy (nieobecnego) i od-twórcy (każdorazowego) - jest sztucznie zaaranżowanym miejscem, z którego energii każdy może zaczerpnąć. Ta szczególna formuła istnienia dzieła sztuki poetyckiej z czasem utrwala się jako niejawny wzorzec, swoisty punkt odniesienia dla liryki jako takiej. Rozpowszechnienie tekstów pisanych paradoksalnie utrwaliło wzór performansu, który faktycznie był już nieczynny, pozwoliło bowiem uczynić go modelowym właśnie. Pojawienie się wiersza do czytania jako wiersza postśpiewanego, przyczyniło się do długiego trwania poezji4

Zapisana piosenka zawiera bowiem sugestię performansu śpiewaka, który śpiewa o sobie nawet wówczas, kiedy faktycznie wciela się w jakąś postać. Nie przypadkiem zresztą jest to najczęściej postać osobowo „neutralna”, czyli postać modelowego poety-śpiewaka - trubadura5. Oto sama poezja niejako

3 „As in Augustine's account of poetry, 'Pus sabers' takes form as it unfolds in performance and its meaning is realized fully only when singing has passed into memory". S. Boynton, Troubadour Song as Performance: A Context for Guiraut Riquier's 'Pus sabers no'm val ni sens'. https://www.academia.edu/8451370/Troubadour_Song_as_Performance_A_Context_for_Guiraut_Riquier_s_Pus_sabers_no.m_val_ni_sens [dostęp: 1.06.2019 r.].

4 Na temat śladów historycznej oralności w tekstach pisanych patrz klasyczne prace: W. J. Ong, Oralność i piśmienność: stowo poddane technologii, tłum. J. Japola, Lublin 1992 oraz P. Zumthor, L'introduction à la poésie orale, Paris 1983.

5 Świadectwem tego jest zmieniające się poczucie podmiotowości autora - od wykonawcy utworu do autora całej „twórczości” lirycznej. Odtąd w autorskim zbiorze poetyckim (jako książce) właściwym przedmiotem/tematem będzie już zawsze sama poezja jako ślad poetyckiego bycia jej autora. Zob. S. Huot, From song to book. The poetics of writing in early French lyric and lyrical narrative poetry, Ithaca 1987. 
przeistacza się w poetę, przemieniając jego osobową egzystencję (w wybranych momentach) w bezosobowe „bycie poetyckie”, co pozwala mu uruchomić w sobie poezjowanie. Autor wiersza, autor liryczny, nawet kiedy nie mówi o sobie, to wypowiada siebie, bo mówiąc o sobie czy nie, zawsze mówi o poecie jako takim ${ }^{6}$. To nie on sam, lecz poezja, która uczyniła go poetą, okazuje się właściwym i stałym bohaterem liryczności. Celem wierszowania jest więc w zasadzie umożliwienie czytającemu wiersz uczestnictwa w przestrzeni emocjonalno-intelektualnej poetyckości (liryczności), która sama z kolei wydaje się szczególnym - bo rewelatorskim - sposobem bycia ${ }^{7}$.

\section{4}

Praktycznie zatem - zobaczmy, co dzieje się w krótkim wierszu Wizyta.

Ciekawa jest siatka rymów. W zasadzie mamy tutaj jeden pełny rym potrójny, przy czym jego środkowa cząstka, wewnątrzwersowa, jest słabo słyszalna: Salomona/zamyślona, bo niejako zdominowana przez końcowy, zamykający rym: Salomona/żona. Słowo „żona” wyraźnie więc kojarzyć się ma ze słowem „Salomon”, figura miłości z figurą mądrości. Ale „zamyślenie” też tu pasuje semantycznie, jest ono jakby łącznikiem wyjaśniającym, przejściem między alegoriami, ukrytym we wnętrzu tego potrójnego akordu. Z kolei odpowiedniość głoskowa, jaka zachodzi między słowami: „serdeczny” i „śmieszny”, to coś więcej niż asonans; chociaż rym pozostaje niedoskonały, szczelinowe złożenia „sz” i „cz” są sobie na tyle pokrewne, że właściwie możemy uznać je za warianty tej samej spółgłoski. Łączy to ze sobą dodatkowo oba słowa i być może podsuwa czytającemu jakąś wspólną dla nich płaszczyznę semantyczną, mieszczącą się na przykład w określeniach: „radosny, przyjazny, beztroski”.

Dźwięki rymów są więc, oprócz końcowego, słyszalne rzadko i nieregu-

6 Szczegóły życia osobistego autora pojawiają się coraz częściej w miarę rozwoju formy poezji trubadurów, ale właśnie dlatego poeta może sobie na nie pozwolić, że jest już uważany za ,poetę” właśnie, a nie za osobę prywatną. Zob. S. Kay, Subjectivity in troubadour poetry, Cambridge 1990.

7 Wiersz liryczny mimowolnie sugeruje, że jest niejako odtworzeniem oryginalnego wykonania, które było faktycznie aktem twórczym; czytelnik zatem zostaje świadkiem działań/doznań poety-śpiewaka. Obie strony tego wydarzenia nie są wówczas sobą indywidualnie, lecz realizują archetypową rolę; wydaje się więc, że wiersz odwołuje się do głębokich pokładów pamięci wspólnotowej. A. Van Vleck, Memory and re-creation in troubadour lyric, Berkeley 1991. 
larnie, za to zaskakujące i semantycznie zasadne. Tym ciekawsze na ich tle będą miejsca bezrymowe, czyli takie, w których rymu byśmy się spodziewali, a nie znajdujemy go. W pierwszej strofie powinien paść rym do słowa „po wszystkim”, ale zamiast niego dostajemy niemal bezrymowe, w dodatku W mocnym miejscu jednowyrazowego zakończenia strofy, słowo „z gwizdkiem”. I słusznie, bo właśnie dzięki temu czajnik nie przepadnie w języku, w mechanicznym powtórzeniu rymu, lecz wyskoczy z tła i stanie czytelnikowi przed oczami. Oczywiście, jakaś resztka głoskowego odbicia pobrzmiewa w zbitkach: ,-zdkiem” i ,-stkim”, ale musielibyśmy chyba w tym miejscu zaakcentować specjalnie, żeby odpowiedniość dała się usłyszeć. Słowa te więc łączą się i nie łączą, za to znaczenia wyraźnie ze sobą kontrastują, bo maleńki, ale buńczuczny, a przez to zauważalny „gwizdek” niewątpliwie przeciwstawia się abstrakcyjnemu słowu „wszystko”, co tym bardziej pozwala mu ściągnąć na siebie uwagę.

Strofika podkreśla końcowe akordy, słyszymy dwukrotnie uderzenie w struny safickiej lutni. Efekt ten wzmacnia wzorzec metryczny, również wykazujący raczej sugestię regularności niż stały porządek. Śpiewak zwykle zaczyna wers od gwałtownego, twardego trocheja, żeby przejść w łagodniejszy daktyl, a chętniej w rozlewny amfibrach. Znowu słychać w tym jakby akompaniament na instrumencie strunowym, kiedy po mocnym uderzeniu następuje zjazd po strunach. Gałczyński zresztą, wbrew pozorom, jakie podsuwa sugestywna śpiewność jego wierszy, nie lubi regularnego metrum, najczęściej pozwala sobie na wariacje rytmiczne, często wprowadza możliwość wariantowej akcentacji, a dłuższe utwory chętnie dzieli na odrębne całostki o różnych strukturach metrycznych. Daje to efekt jakby żywego wykonania.

Podsumowując zatem: forma wersyfikacyjna uwydatnia lekkość i pewną nonszalancję; będąc wszakże pozbawiona typowych wyznaczników muzyczności, faktycznie zawiera elementy wskazujące na performatywne raczej niż kompozycyjne intencje twórcy, bo gromadzi efekty dźwiękowe w funkcji nie tylko ornamentacyjnej, lecz również semantycznej i pragmatycznej. Pomiędzy dwiema strofami słychać na przykład zmianę tonu: z zabawnego na niby-poważny, a w istocie autoironiczny, zaś retoryczne figury, służące nawiązaniu kontaktu z odbiorcą komunikatu, wzmagają perlokucyjną moc wypowiedzi. Wydaje się, że poeta bawi się ze swoim gościem i po trosze też bawi się nim, nieustająco igrając z jego reakcjami, które bacznie obserwuje. Rezultatem 
wszystkich tych chwytów tekstotwórczych będzie obrazek przedstawiający figurę śpiewaka-trefnisia, lirycznego kpiarza, wymachującego ramionami i podśpiewującego pod nosem. Wchodząc ufnie w jego prywatną przestrzeń, czytelnik daje się obsadzić w roli widza maleńkiego przedstawienia: ogląda dworską scenkę, przedstawiającą przestylizowany dworski ukłon.

Brak spodziewanego rymu w zakończeniu pierwszej cząstki sprawia, że czytający podnosi kadencję, jednocześnie to samo czyni formuła pytania, i to podwójnego, bo z pytajnikiem wtrąconym po słowie „prawda”; pytania zrealizowanego wszakże jako stwierdzenie, a więc znowu zaskakująco. Podwójnie mocny, tępo pusty brak spadku frazowania daje efekt znaczącej pauzy, zawieszenia głosu. Nie sposób nie zatrzymać uwagi na tym wersie, nie zatrzymać toku lektury, a więc i nie zatrzymać wzroku na wskazanym przedmiocie (czajniku), żeby zaraz potem, z niejaką konsternacją, jakby szukając dodatkowego wyjaśnienia (a co w tym szczególnego?), spojrzeć na mówiącego gospodarzapoetę. W takiej ciszy, dopiero w takim natężeniu słuchowej uwagi usłyszeć można słaby dźwięk: mruczenie, więc poeta-gospodarz, wpatrzony w oczy gościa, podnosi palec i podejmuje cicho swoją piosenkę, wskazując na nieobecnego kota. Kot ma na imię Salomon, jest więc wcieleniem mądrości. To mruczenie, ta mądrość, to dosłownie nieznaczący pomruk, jakby sama obecność starożytnej władzy sądzenia. W moim domu, w domu poety, tak mimochodem zdaje się gospodarz informować gościa, mieszka mądrość biblijna, ale skrywa się i daje o sobie znać tylko w momentach natężonej uwagi, wywołanej absurdalnym podważeniem nieuważnego widzenia. To jest sekret tego domu, sekret wyjawiony wprawdzie, ale znowu paradoksalnie, bo tylko po to, żeby gość zachował go w tajemnicy, nie co innego wszak znaczy idiom ,powiedzieć coś komuś w sekrecie”. Zapraszając gościa do siebie, poeta dopuszcza go więc do tajemnicy swojego intymnego wnętrza, tam zaś rezyduje... największa mądrość człowiecza. Mądrość ta nie przemawia słowem do pojęcia, lecz ciągłym niepojętym murmurandem towarzyszy człowiekowi w codzienności, obecnością swoją świadcząc o samej tylko ważności „sekretu”, który reprezentuje.

Wcześniej jednak pojawił się czajnik. Jedyny przedmiot, na który zapraszający zwraca uwagę wchodzącego, zachęciwszy go wprzódy do rozejrzenia się ,po wszystkim”. Dlaczego więc właśnie czajnik, i tylko on jeden? Gospodarz przedstawia ten pospolity sprzęt domowy (są więc chyba w kuchni, a więc w najbardziej „swojskim” miejscu gospodarstwa) jakby był on do- 
mownikiem, bytem niemalże obdarzonym duszą, jakimś domowym duszkiem. Czajnik wyróżnia się tym, że jest śmieszny, bo posiada gwizdek. Czy należy z tego wnosić, że śmieszny jest jego wygląd, czy czynność, którą wykonuje? Czajnik z gwizdkiem wygląda faktycznie trochę dziwacznie, jakby nadrealnie; oto przecież doskonałej półkuli pod harmonizującym z nią półkolem doczepiono zadarty nosek, buńczucznego kogucika, który pieje cienkim głosem, monotonnie i za głośno. Czajnik to beztroski zawadiaka, przeciwieństwo poważnego kota. Jego śmieszność wywołuje zapewne uśmiech gościa, a zauważenie absurdalnej natury najzwyklejszego przedmiotu rozluźnia atmosferę. Gospodarz ofiaruje gościowi to poczucie psychicznego komfortu po to, by wyprowadzić go niejako ze stanu pragmatycznego traktowania rzeczywistości dookolnej. Chodzi o baczenie na osobność rzeczy każdej, każda bowiem może mieć duszę, może być w istocie bytem niemal osobowym.

Jesteśmy w domu poety, czyli w świecie sztuki i mądrości, pośród rzeczy uduchowionych, a każda daje o osobie znać, aczkolwiek niczego nie wyjaśnia, raczej odwrotnie - utrwala swoją tajemniczą naturę, bezpretensjonalnie wszakże. Poetę cechuje przecież zarazem pycha i dyskrecja, poetycki język wymaga lekkości i swobody, ale ostatecznym celem poetyckiego sposobu bycia jest powaga i skupienie - bo to dzięki nim rzeczywistość pozwala doświadczyć się w swojej prawdziwej postaci. Wiersz-piosenka, wiersz-scenka otwiera oczy jednako poecie i jego słuchaczowi, gospodarzowi i gościowi poetyckiego gospodarstwa. Za sprawą swojej lekkiej formy wprawia on czytającego w stan relaksacji, dzięki czemu uwalnia jego myśl od spetryfikowanych sposobów percypowania świata, przemieniając spodziewane w zadziwiające.

Atoli - nie koniec na tym. Zakończenie wiersza dodaje do tego, kompletnego zdawałoby się obrazu, jeszcze coś - kobietę, partnerkę poety, a w praktyce jej portret. Kobieta $\mathrm{z}$ kwiatami nie jest ani przedmiotem, ani dźwiękiem, jest obrazem. A właściwie jest zobrazowaniem - przemienieniem w obraz osoby żywej! Albo odwrotnie - jest takim obrazem, w którym zobrazowane uobecnia się, ożywa... Tak czy inaczej: to, ku czemu teraz zwracają swoje baczenie poeta i jego gość, to - veraikon - ikoniczne przedstawienie realnej osoby, a właściwie jej duchowego aspektu w postaci wizerunku ciała. Jest to ciało kobiety-żony, a więc, z punktu widzenia poety, damy jego serca, uwznioślonego przedmiotu adoracji, w którym poezja i miłość łączą się w jedno - jak dzieje się to w pieśniach trubadurów. 
Ikoniczność i alegoryczność poetyckiego obrazu nie przesłaniają wszakże realności wydarzenia. Przecież zamyślona kobieta nie jest martwa. Ona tylko właśnie wróciła z ogrodu, trzyma w rękach ścięte kwiaty, przysiadła na chwilę i pogrążyła się w myślach tak głęboko, że nie zauważyła chyba wejścia gościa. Za to obaj mężczyźni zauważają ją, choć może raczej należałoby powiedzieć: zważają na nią, wyostrzywszy uprzednio zmysły swojej uważności na dziwnym przedmiocie i na tajemniczym głosie.

Dramaturgia wydarzenia w tym wierszu to właściwie jeden akt przedłużającego się gestu, jakim zwykliśmy zapraszać wchodzących. Poeta-gospodarz najpierw wskazuje dłonią na czajnik, potem podnosi palec, nakazując przybyszowi zasłuchanie, wreszcie znowu opuszcza ramię, może dokłada drugą rękę. W takiej postawie otwarcia, akceptacji, adoracji nawet, odwraca się razem ze swoim towarzyszem ku innej stronie domu - tam, gdzie mieści się część gospodarstwa jeszcze bardziej intymna niż owa swojska kuchnia - ku miejscu wspólnego z żoną przeżywania codzienności. Wcielone w ukochaną kobietę myśl i natura czynią z jej ikonicznej postaci wcielenie sztuki, która jest codzienną i najbliższą towarzyszką życia poety, gospodynią jego duchowego gospodarstwa. Złączony ślubem z ikoną poezji trubadur nie istnieje poza tym związkiem, każdy jego wiersz i każde pieśni wykonanie będzie rodzajem adoracji hierofanii.

Semantyka gestów w nieopisany sposób uobecnionych w opisie tej sceny pozwala rozpoznać nie tylko empatię, uważność i adorację, których symptomem są skonwencjonalizowane ruchy rąk, lecz odsłania również subtelniejszy symptom - ruch oczu. Spojrzenie zrazu szybkie, punktowe na śmieszny przedmiot, przemienia się nagle $\mathrm{w}$ zatrzymany ruch oczu zastygłych w zasłuchaniu delikatnego mruczenia, żeby w końcu przenieść się na siedzącą w zamyśleniu kobietę. Jak na nią patrzy każdy z dwóch mężczyzn? Zapewne tak oto: gość próbuje nawiązać kontakt wzrokowy, chyba bezskutecznie, gospodarz natomiast raczej znajduje ten kontakt natychmiast, w końcu to najbliższa mu osoba. Wyobrażam sobie, że mąż i żona porozumiewają się wzrokiem, jak to zwykle bywa, kiedy gość dom nawiedzi niespodziewanie, zakłócając intymną wspólnotę małżonków. Ale porozumienie między poetą a jego damą nie ogranicza się do wzajemnego rozpoznania się osób. To zarazem moment rozpoznania się poety w swojej wybrance, we wcielonej w nią poezji; rozpoznania, które przygotował sobie uprzednio, ćwicząc się w uważności. 
5

Gdyby pokusić się o wyszukanie analogicznej dla tego wiersza formy w katalogu meliki greckiej, należałoby go uznać za miniaturową odmianę hymnu kletycznego, czyli zapraszającego na ucztę, lub w inne miejsce ukontentowania. Zapraszano każdego, przy czym najczęściej chodziło o jakiegoś boga, ewentualnie lokalnego demona, którego obecność miałaby niejako podnieść rangę wydarzenia, jakże przyziemnego w swoich emocjonalno-zmysłowych skutkach, zaś samą tę istotę duchową uczcić na ludzką miarę skromnego gospodarstwa poety. $\mathrm{Z}$ czasem tematyka hymnu kletycznego zawęziła się do obszaru, w którym poeta zamieszkuje jako poeta właśnie, który zatem stanowi jego pracownię i azyl, rodzaj świątyni, miejsca, gdzie uruchamiała się energia tworzenia wiersza, a więc działa się jakby liturgia słowa przemieniającego się w pieśń. Zaproszenie na tę uroczystość codziennej twórczej pracy poeta kierował więc $\mathrm{w}$ istocie do ukrytego $\mathrm{w}$ głębiach własnej wrażliwości ducha poezjowania, którego musiał przywołać i zachęcić do pozostania, tak jak, bardziej konwencjonalnie, przywołuje się muzę w otwierającej poemat apostrofie.

Popularnym przykładem takiego utworu jest fraszka Kochanowskiego Na lipę. Kiedy bowiem autor mówi w niej: „Gościu, siądź pod mym liściem, a odpocznij sobie", to wiemy z góry, że w istocie do swojego ogrodu i domu, i pracowni jednocześnie - zaprasza samego siebie. Praktykował wszak w tej szczególnej przestrzeni poezjowanie niejeden raz, doświadczył tam poetyckiego natchnienia i chciałby to znowu powtórzyć. Ten poetycki warsztat i domowy azyl okazuje się jednak zazwyczaj miejscem zwyczajnym, zakorzenionym w świecie rzeczywistym, w naturze lub w ludzkim gospodarstwie. W czarnoleskim domu szlachcica mamy obie przestrzenie w jednym, a na dodatek całe to uniwersum naznaczone jest symbolami poetyckości: lipa miodopłynna, pszczoła miodorodna, słońce rozszczepione na promienie, bo padające przez szczeliny między liśćmi. A jeszcze i wiatr tchnie w uszy, pod szpacze narzekania podkładając basso contiunuo. $\mathrm{Z}$ ust poety zaś wydobywa się szept, sen przynoszący, a więc łagodzący trudy przytomnego życia. Wszystko to motywy antyczne, ale renesansowy poeta chrześcijański robi oczywiście zwrot przez rufę i na koniec podsuwa pod mitologiczne toposy biblijny obrazek, z nieco ironicznym przecież wdziękiem i dwornością, jakby trochę zażenowany tym nazbyt religijnym finałem epikurejskiej pieśni. 
Kochanowski nazywa swój wiersz fraszką, choć w istocie ma on formę hymnu pochwalnego na cześć ogrodu - zorganizowanej ludzkim staraniem natury. Czarnoleski gospodarz wybiera tonację lekką, jakby nie chciał swojego gościa onieśmielić zbytnim ambarasem, gdyż tak tylko uda mu się wprowadzić go w splendor świata poetyckich toposów, które poeta zna, bo ich na co dzień doświadcza, ale jego gość mógłby wśród nich poczuć się obco. Frywolność słyszalna w głosie gospodarza ma więc składającemu wizytę ułatwić wejście do nowej, cudzej przecież, przestrzeni, rozgoszczenie się w niej, a w końcu łagodne, jakby mimowolne zaakceptowanie jej jako czegoś nieoczekiwanie „swojego”. Z kolei wiersz Gałczyńskiego wydaje się notatką, szkicem zaledwie, opartym na kilku drobiazgach obrazkiem pospolitego domowego wnętrza. Przedmioty, które mistrz Ildefons wymienia, na które gestem słownym wskazuje, to rzeczy ostentacyjnie wręcz zwyczajne. Powtórzone „proszę, proszę" zdradza, że gość chyba nieco onieśmielony, w końcu nie co dzień odwiedza się sławnego poetę, trzeba go więc uspokoić, że przecież nic w tym nadzwyczajnego, że nijaka oficjalność czy wzniosłość go tu nie spotka. Mimochodem puszczona zachęta okazuje się jednak lekcją uważności, nader skuteczną zapewne właśnie dzięki nienatrętnej, banalnej wręcz formie, a raczej: dzięki ostentacyjnie bezpretensjonalnej tonacji głosu.

Poeta wylicza więc owe ,przedmioty zwyczajne”, tym samym mimowolnie nadając im rangę maleńkich cudów. Aranżacja przestrzeni jest statyczna, ale gest poety niejako animuje przedmioty, bo przecież czajnik wydaje się zadzierać śmiesznie swój wystający gwizdek, kot pomrukuje gdzieś z niewidzialności, a kobieta emanuje spokojem i czarem. Wszystko to ożyje dzięki wykreowanej aurze bezpieczeństwa, które okazuje się warunkiem postrzegania rzeczy w aureoli wartości. Gość zachęcany będzie do tego, by „rozejrzał się dokładnie”, ośmielony przy tym „,serdecznością” zaproszenia. Serdeczność to odwołanie do tego, co w sercu, czyli zwrot do samej esencji człowieczeństwa, do jedyności osoby, ale też to właśnie dzięki serdeczności nawiązujemy przecież intymny kontakt z kimś zrazu obcym, a zaraz potem współmieszkańcem wspólnego (bo przecież gość czuć się ma ,jak u siebie”) gospodarstwa. Z kolei „patrzenie dokładne” to takie, które obdarza przedmioty skupieniem umysłu; to zauważanie ich wyjątkowości, a zatem czynność wymagająca pewnego wysiłku duchowego, natężenia woli w akcie życzliwości. Objęcie uwagą rzeczy na co dzień spostrzerzeniem właśnie nieobdarzanych sprawia, 
że przemieniają się one w rzeczy niezwyczajne, zaś przebywanie wśród nich staje się byciem odświętnym.

\section{6}

Pod wpływem porozumiewawczego spojrzenia wiersza, który wysyła ku czytelnikowi utrwaloną w porządku słów energię „zapatrzenia się” i „rozpoznania się" w oczach poślubionej, ulega rozbiciu racjonalno-pragmatyczna skorupa umysłu, mająca postać zaskorupiałego w swojej utylitarnej funkcji języka. Na moment (zbyt krótki, by cokolwiek zrozumieć, ale wystarczająco intensywny, by odczuć semantyczny impuls) w umysł wpada promień jakby z zewnątrz, który jednakowoż ma naturę podobną (zaiste cudem) światłu świadomości, żeby wniknąć w najmniejszą cząstkę trwania, a więc faktycznie w bezczasowość naszego umysłowego bycia w świecie. Porozumienie we wzajemnym spojrzeniu uruchamia w nas energię współprzeżywania, dzięki czemu udaje się nam rozjaśnić we własnym umyśle ciemną plamkę codziennego niewidzenia siebie... Po to, aby Cogito mogło doświadczyć prymarnej pewności swojego Sum jako czegoś, co było od zawsze zarazem transcendentne wobec samowiedzy - a więc jej zapewne darowane, i jej tylko jednej immanentne jako esencja Subiectum.

Tego wydarzenia iluminacji doświadczamy pod postacią refleksji, odblasku, czyli myśli wysłanej w ciemność i wróconej stamtąd z ładunkiem światła, aliści przesłanej tak prędko, że nieuchwytnej żadnym zwerbalizowanym rozumieniem. Wymiana emocji pomiędzy rozumiejącymi się spojrzeniami, podobnie jak wymiana iluminacji hermeneutycznej - jaka zachodzi między tekstem wiersza emanującego sensem a czytającym ów wiersz w poczuciu kontaktu $\mathrm{z}$ jego przesłaniem - następuje nie tyle jednocześnie, ile jakby z pominięciem następstwa. Można nie tylko tego doświadczyć, ale można to również utrwalić i przechować, a potem odzyskać.

Do tego właśnie służą wiersze, szczególnie te, które robią do nas oko na wpół serio. Porozumiewawczo mrugając na ulegającego ich urokowi czytelnika, nawiązują z nim rodzaj flirtu, który oczywiście nie rozwiąże się w żadną rozwiązłość... Bo i z kim, skoro wiersz zjawia się zawsze pod nieobecność mówiącej nim osoby? Taki wiersz, śpiewnie nierozumny, prowansalsko słodki, zaprasza tego, komu wpadnie w ucho, do współudziału we wspólnej uciesze, ale zaczepiony piosenką wybranek poety nie stara się odpowiedzieć mu 
ani interpretacją, ani nawet egzaltowaną reakcją, lecz poprzestaje na samej radości współuczestniczenia w spotkaniu.

Powrót słowa rozświetlonego rozumiejącą akceptacją, powrót wehikułem wiersza powoduje oniemienie raczej niż odzew, zamilknięcie, które robi miejsce temu jedynemu wysłowieniu dlatego tylko, że ono właśnie zaszło. Owa zaś niemota nasuwa podejrzenie, że to nie wiedza ma być korespondencji treścią, lecz satysfakcja - czysta, bo absolutnie bezinteresowna - taka, która uśmiech pogodny wywołuje, a więc obdarza jeżeli nie szczęśliwością, to na pewno pocieszeniem.

\section{Bibliografia}

Chaudhury P. J., Indian Poetics, "The Journal of Aesthetics and Art Criticism" 1965, Vol. 24, No. 1. Dostęp przez: https://www.jstor.org/stable/428209?seq=1\#page_ scan_tab_contents [1.06.2019 r.].

Holmes O., Authority and Materiality in the Italian Songbook: From the Medieval Lyric to the Early Modern Madrigal. Dostęp przez: https://www.academia. edu/39177439/Authority_and_Materiality_in_the_Italian_Songbook_From_the_ Medieval_Lyric_to_the_Early_Modern_Madrigal [1.06.2019 r.].

https://www.academia.edu/8451370/Troubadour_Song_as_Performance_A_Context_for_Guiraut_Riquier_s_Pus_sabers_no.m_val_ni_sens [1.06.2019 r.].

Huot S., From song to book. The poetics of writing in early French lyric and lyrical narrative poetry, Ithaca 1987.

Kay S., Subjectivity in troubadour poetry, Cambridge 1990.

Ong W. J., Oralność i piśmienność: słowo poddane technologii, tłum. J. Japola, Lublin 1992.

Van Vleck A., Memory and re-creation in troubadour lyric, Berkeley 1991.

Zumthor P., L'introduction à la poésie orale, Paris 1983. 